\title{
METHODS OF EXPERIMENTAL VERIFICATION OF STEINER THEOREM IN PHYSICAL PRACTICUM AND LABORATORY WORK
}

\author{
Zharilkasin Iskakov ${ }^{1}$
}

\begin{abstract}
In this paper, the technique of laboratory work on experimental verification of Steiner's Theorem in laboratory conditions is developed. To do this, specially designed experimental device was used. The main part of such device is a simple physical pendulum, swinging freely about the axis of suspension, consisting of a cylindrical disc set on a thin rod. To determine the moment of inertia of cylindrical body about the axis of vibrations, property of a physical quantity additivity was used. When processing experimental results, functional approximation by a least squares method was applied; as a result, the empirical expression of Steiner's Theorem was achieved. Results of experimental studies were very close to the results of theoretical calculations. Laboratory work can be easily repeated for a body of arbitrary shape. The methodology used can be recommended for physical practicum in universities as an effective and easy way of experimental verification of Steiner's theorem.
\end{abstract}

UDC Classification: 531, 7, DOI: http://dx.doi.org/10.12955/cbup.v2.480

Keywords: inertia, moment, Steiner's Theorem, experimental verification

\section{Introduction}

Physical laboratory practicum is an experimental study of physics, supported by modern educational equipment. The purpose of laboratory practicum is training of strong competitive specialists with university quality of basic training and skills of practical application of knowledge. Laboratory practicum is focused on the development of intelligence of a student, increasing interest to a subject, acquisition of ability to create. Providing intensive training, laboratory practical work solves the problem of quality education in conditions of shortage of teaching time.

In the physical laboratory works of Evgrafova \& Kagan (1970) and Korzun (1991), practical instructions of Baypakbayev, Karsybayev, \& Salamatina (2007), and many other laboratory works, learning of free mechanical vibrations and determination of gravitational acceleration are done by means of physical reversible pendulum by Bessel's Method. Article of Akimov, Baranov \& Saletsky (2000) describes ways to improve the accuracy of measurement of gravitational acceleration through a training physical pendulum. The formulae for determining the error estimation of the gravitational acceleration $(g)$ were obtained.

A method for increasing the accuracy of determining of the gravitational acceleration $(g)$ in conditions of university laboratory is proposed. The guidelines of Baypakbayev, Zavadskaya, Tonkonogaya, \& Semeneniya (2008) study free oscillations on the model of a simple pendulum; the accuracy of implementation of this model in a laboratory conditions is estimated. The result is determination of amplitude range, in which the oscillation period remains constant with a given accuracy. Also the damping effect within oscillation period is investigated; it is checked to determinie whether a linear relationship between the square of oscillation period and the length of the suspension is experimentally confirmed. The article of Korzun (1991) experimentally studies the natural oscillations of springactuated pendulum, stiffness coefficient of spring, the oscillation period, and friction coefficient of pendulum in a viscous medium. The practicum of Astapov et al. (2011) identifies the characteristics of damped oscillations of a physical pendulum. Work of Kachevskiy (1998) defines, besides characteristics of damped oscillations of a physical pendulum, internal friction of the mechanical system, and characteristics of material—-the damping capacity and the shear modulus.

Pendulums were used not only for the experimental study of free mechanical vibrations, but also for experimental determination of inertia moment of the pendulum and experimental verification of

\footnotetext{
${ }^{1}$ Zharilkasin Iskakov, Almaty University of Energy and Communications, Kazakhstan, iskakov53@mail.ru
} 
Steiner's Theorem. In the works of Evgrafova \& Kagan (1970), Astapov et al. (2011), Maysova (1970) and methodological guidelines of Baypakbaev, Karsybaev, \& Salamatina (2007), the measurement of inertia moment of the body was affected by observation of torsional oscillations; herewith, the task of experimental determination of inertia moment of the oscillating body was solved on the basis of energy conservation law. The article of Gladun et al. (2004) presented a lab work to determine the principal moments of inertia of solids and to build central ellipsoid of inertia using torsional vibrations. Unlike previous work, Vasiliev, Saletsky, \& Slepkov (2000) have determined the inertia tensor at an arbitrarily chosen coordinate system, rigidly attached to the body. The experiment idea is based on connection of inertia tensor components with the moments of inertia in rotation relative to fixed axes. If previous authors used physical pendulum to study free linear oscillations, Koryavov (2003) used it for study of nonlinear oscillations. He suggested a pendulum, which allows us to investigate the violation of isochronism of oscillations by increasing their amplitude, in laboratory conditions, when the measurement of oscillation period cannot be carried out with great precision.

The aim of this work is to develop, in physical laboratory practicum, the methods of experimental verification of Steiner's Theorem and to study free mechanical vibrations with a simple physical pendulum.

\section{The experimental device and methods of experimental verification of Steiner's Theorem}

The experimental device, shown in Figure 1, consists of a physical pendulum suspended on bracket (1), photoelectric sensor (2), connected to it by an electronic stopwatch (3) and oscillations counter (4), and an angle scale (5). Physical pendulum is a cylindrical disc (6), fitted to a thin rod with notes (7), attached with a screw (8). Unlike the device model proposed by Evgrafova \& Kagan (1970), a cylindrical disc can be moved freely along the rod and can be secured in a required place. Also, there are discs of different masses with longitudinal and transverse cylindrical holes. Time and number of oscillations is automated. The front panel of the body has three key switches, which are POWER, RESET, and STOP, and digital indicators-highlighting the readings of stopwatch and oscillations counter.

\begin{tabular}{|l|l|}
\hline Figure 1: The experimental device shown from front view (a) and side view (b) \\
\hline
\end{tabular}


Now we present the methodology of the experimental verification of Steiner's Theorem in educational laboratory settings. Initially, the experiment was carried out with an unloaded pendulum, i.e. with the rod. First, we verify the initial position of the pendulum by means of support screws (to match of arrow on zero point of the scale). Then, we offset a pendulum from its equilibrium position to the left for $A_{0}=5$ scale divisions, turn on a stopwatch and oscillations counter, push the POWER button, and release the pendulum, enabling it to swing freely. Next, we measure the duration $(t)$ using a stopwatch, corresponding $n=50$ oscillations, push the STOP button. By pushing the RESET button, we clear the readings of the stopwatch and oscillations counter to zero. Dismissing the pendulum to the right, we repeat the experience from the same division of angle scale. Now we continue the experiment with a loaded pendulum. Cylindrical disc of smallest mass $\left(m_{b}\right)$ is placed on a thin rod from a free end and screwed on the shortest distance $\left(z_{b}\right)$ from the point of suspension. Then, repeat the previous steps of the experiment. Release the cylindrical disc down to the next mark $\left(z_{b}\right)$ of the rod, we repeat the first stage of the work. The measurement results are recorded in Table 1a. Then, we repeat the experiment with pendulum with heavier discs. The results are recorded in Table $1 \mathrm{~b}$ and Table 1c.

\begin{tabular}{|c|c|c|c|c|c|c|c|c|c|}
\hline \multirow{2}{*}{$\begin{array}{l}\mathbf{m} \\
(\mathrm{kg})\end{array}$} & \multirow{2}{*}{$\begin{array}{l}\mathrm{z}_{\mathrm{b}} \\
(\mathrm{m})\end{array}$} & \multirow{2}{*}{$\begin{array}{l}\mathrm{z}_{\mathrm{c}} \\
(\mathrm{m})\end{array}$} & \multicolumn{3}{|c|}{ t (s) } & \multirow[t]{2}{*}{$\mathrm{T}(\mathrm{s})$} & \multirow{2}{*}{$\begin{array}{c}\mathbf{I} \cdot 10^{-} \\
{ }^{3}\left(\mathbf{k g} \cdot \mathbf{m}^{2}\right)\end{array}$} & \multirow{2}{*}{$\begin{array}{c}\mathbf{I}_{\mathbf{b}} \cdot \mathbf{1 0}^{-} \\
{ }^{3}\left(\mathbf{k g} \cdot \mathbf{m}^{2}\right)\end{array}$} & \multirow{2}{*}{$\begin{array}{c}I_{\mathbf{t}} \cdot 10^{-} \\
{ }^{3}\left(\mathrm{~kg} \cdot \mathrm{m}^{2}\right)\end{array}$} \\
\hline & & & left & right & Average & & & & \\
\hline 0.08 & - & 0.25 & 58.43 & 58.42 & 58.43 & 1.17 & 6.86 & - & 6.56 \\
\hline \multirow[t]{5}{*}{0.29} & 0.08 & 0.13 & 48.01 & 48.02 & 48.02 & 0.96 & 8.51 & 1.65 & 1.36 \\
\hline & 0.13 & 0.16 & 47.64 & 47.63 & 47.64 & 0.95 & 10.89 & 3.27 & 3.58 \\
\hline & 0.18 & 0.20 & 49.23 & 49.23 & 49.23 & 0.99 & 14.07 & 7.21 & 6.85 \\
\hline & 0.23 & 0.23 & 51.78 & 51.78 & 51.78 & 1.04 & 18.40 & 11.54 & 11.17 \\
\hline & 0.28 & 0.27 & 54.71 & 54.71 & 54.71 & 1.09 & 23.67 & 16.81 & 16.55 \\
\hline
\end{tabular}

Source: Author

Table 1b: The results of measurements and calculations at $\mathrm{m}_{\mathrm{b}}=0.31 \mathrm{~kg}$

\begin{tabular}{|c|c|c|c|c|c|c|c|c|c|}
\hline \multirow{2}{*}{$\begin{array}{c}\mathrm{m} \\
(\mathrm{kg})\end{array}$} & \multirow{2}{*}{$\begin{array}{c}\mathbf{z}_{\mathrm{b}} \\
(\mathrm{m})\end{array}$} & \multirow{2}{*}{$\begin{array}{l}\mathbf{z}_{\mathrm{c}} \\
(\mathrm{m})\end{array}$} & \multicolumn{3}{|c|}{ t (s) } & \multirow[t]{2}{*}{$T(s)$} & \multirow{2}{*}{$\begin{array}{c}\mathrm{I} \cdot \mathbf{1 0}^{-} \\
{ }^{3}\left(\mathrm{~kg} \cdot \mathrm{m}^{2}\right)\end{array}$} & \multirow{2}{*}{$\begin{array}{c}I_{b} \cdot 10^{-} \\
3\left(\mathrm{~kg} \cdot \mathrm{m}^{2}\right)\end{array}$} & \multirow{2}{*}{$\begin{array}{c}I_{t} \cdot 10^{-} \\
{ }^{3}\left(\mathrm{~kg} \cdot \mathrm{m}^{2}\right)\end{array}$} \\
\hline & & & left & right & Average & & & & \\
\hline \multirow[t]{5}{*}{0.39} & 0.08 & 0.11 & 45.29 & 45.28 & 45.29 & 0.91 & 9.20 & 2.34 & 2.00 \\
\hline & 0.13 & 0.15 & 45.49 & 45.48 & 45.49 & 0.91 & 12.53 & 5.67 & 5.27 \\
\hline & 0.18 & 0.19 & 49.82 & 47.79 & 47.81 & 0.96 & 17.42 & 10.56 & 10.09 \\
\hline & 0.23 & 0.23 & 50.97 & 50.96 & 50.96 & 1.02 & 23.77 & 16.91 & 16.47 \\
\hline & 0.28 & 0.27 & 54.37 & 54.37 & 54.37 & 1.09 & 31.69 & 24.52 & 24.40 \\
\hline
\end{tabular}

Source: Author

To calculate the arithmetic mean of the oscillation duration $(t)$ and the period of oscillation $(T)$, we use the following formula:

$$
T=\frac{t}{n}
$$


Coordinate of the pendulum's center of gravity (Saveliev, 2012) is calculated by formula:

$$
z_{C}=\frac{m_{b} z_{b}+m_{r} \frac{l}{2}}{m_{b}+m_{r}}
$$

The moment of inertia of a physical pendulum (Haykin, 2008) is:

$$
I=\frac{m g z_{C}}{4 \pi^{2}} T^{2}
$$

where, $m=m_{b}+m_{r}$ is the mass of a physical pendulum.

Here, body mass $\left(m_{b}\right)$ includes a mass of the disc with holes $\left(m_{h}\right)$ and a mass of screws $\left(m_{s}\right) ; m_{r}$ and $l$ are mass and length of the rod, respectively.

Using the property of additivity of the moment of inertia value (Trofimova, 2008), we calculate the moment of inertia of a cylindrical body as the difference between the moment of inertia of a physical pendulum $(I)$ and the moment of inertia of the rod $\left(I_{r}\right)$,

$$
I_{b}=I-I_{r}
$$

The results of calculations are assigned in appropriate tables. For all values of disc mass $m_{b 1} \prec m_{b 2} \prec m_{b 3}$, we construct a graph of the moment of inertia of a cylindrical body (disc) against distance between the point of suspension and the center of the body, $I_{b}=I_{b}\left(z_{b}^{2}\right)$. To build the graph for $I_{b}=I_{b}\left(z_{b}^{2}\right)$, we use an approximation function by the least squares method (Diakonov, 1987):

$$
I_{b}=a_{0}+a_{2}\left(z_{b}^{2}\right)
$$

where,

$$
a_{2}=\frac{N \sum_{i=1}^{N}\left(z_{b}^{2}\right)_{i} I_{b i}-\sum_{i=1}^{N}\left(z_{b}^{2}\right)_{i} \sum_{i=1}^{N} I_{b i}}{N \sum_{i=1}^{N}\left(z_{b}^{2}\right)_{i}^{2}-\left[\sum_{i=1}^{N}\left(z_{b}^{2}\right)_{i}\right]^{2}}
$$

and,

$$
a_{0}=\frac{1}{N}\left[\sum_{i=1}^{N} I_{b i}-a_{2} \sum_{i=1}^{N}\left(z_{b}^{2}\right)_{i}\right]
$$

This formula is essentially an empirical expression of Steiner's Theorem.

Error coefficients $a_{2}$ and $a_{0}$ are respectively equal (Gladun et al., 2004), thus,

$$
\sigma_{a_{2}} \approx \frac{1}{\sqrt{N}} \sqrt{\frac{N \sum_{i=1}^{N} I_{b i}^{2}-\left(\sum_{i=1}^{N} I_{b i}\right)^{2}}{N \sum_{i=1}^{N}\left(z_{b}^{2}\right)_{i}^{2}-\left[\sum_{i=1}^{N}\left(z_{b}^{2}\right)_{i}\right]^{2}}-a_{2}}
$$


and,

$$
\sigma_{a_{0}}=\frac{\sigma_{a_{2}}}{N} \sqrt{N \sum_{i=1}^{N}\left(z_{b}^{2}\right)_{i}^{2}-\left[\sum_{i=1}^{N}\left(z_{b}^{2}\right)_{i}\right]^{2}}
$$

\begin{tabular}{|c|c|c|c|c|c|c|c|c|c|}
\hline \multirow[t]{2}{*}{ m (kg) } & \multirow[t]{2}{*}{$\mathrm{z}_{\mathrm{b}}(\mathrm{m})$} & \multirow[t]{2}{*}{$\mathbf{z}_{\mathrm{c}}(\mathbf{m})$} & \multicolumn{3}{|c|}{ t (s) } & \multirow[t]{2}{*}{$T$ (s) } & \multirow{2}{*}{$\begin{array}{c}\mathbf{I} \cdot 10^{-} \\
{ }^{3}\left(\mathrm{~kg} \cdot \mathrm{m}^{2}\right)\end{array}$} & \multirow{2}{*}{$\begin{array}{c}\mathbf{I}_{\mathrm{b}} \cdot 10^{-} \\
{ }^{3}\left(\mathrm{~kg} \cdot \mathrm{m}^{2}\right)\end{array}$} & \multirow{2}{*}{$\begin{array}{c}I_{\mathbf{t}} \cdot 10^{-} \\
{ }^{3}\left(\mathbf{k g} \cdot \mathrm{m}^{2}\right)\end{array}$} \\
\hline & & & left & right & average & & & & \\
\hline \multirow[t]{5}{*}{0.49} & 0.08 & 0.11 & 43.44 & 43.44 & 43.44 & 0.87 & 9.96 & 3.10 & 2.65 \\
\hline & 0.13 & 0.15 & 44.22 & 44.23 & 44.23 & 0.89 & 14.38 & 7.52 & 6.96 \\
\hline & 0.18 & 0.19 & 47.05 & 47.05 & 47.05 & 0.94 & 20.85 & 13.99 & 13.34 \\
\hline & 0.23 & 0.23 & 50.50 & 50.52 & 50.51 & 1.01 & 29.17 & 22.31 & 21.76 \\
\hline & 0.28 & 0.27 & 54.26 & 54.27 & 54.26 & 1.09 & 29.76 & 32.90 & 32.24 \\
\hline
\end{tabular}

Source: Author

We can compare experimental graphs with the graphs drawn from the theoretical formula of Steiner's theorem, $I_{t}=I_{O}+m_{b}\left(z_{b}^{2}\right)$.

Considering the small effect of longitudinal holes, $I_{O}$ is the moment of disc inertia relative to an axis, passing through its center and parallel to its generatrix, and can be calculated using the following formula:

$$
I_{O}=\frac{1}{2} m_{h}\left(r^{2}+r_{1}^{2}\right)+\frac{1}{2}\left(m_{s 1} r_{1}^{2}+m_{s 2} r_{2}^{2}\right)
$$

where, $m_{h}$ is the mass of an annular disc; $r$ and $r_{1}$ are its outer and inner radii, respectively; $m_{s 1}$ and $m_{s 2}$ are the masses of the main and head parts of fixing screw, respectively; $r_{2}$ is the radius of head part of the screw.

To carry out further calculations, the following parameters of the pendulum have been used:

$$
\begin{aligned}
& m_{r}=0,082 \mathrm{~kg} ; \mathrm{l}=0,49 \mathrm{~m} ; m_{h}=0,2 ; 0,3 ; 0,4 \mathrm{~kg} ; r=0,06 \mathrm{~m} ; r_{1}=2,45 \cdot 10^{-3} \mathrm{~m} ; \mathrm{m}_{\mathrm{s} 1}=2,22 \cdot 10^{-3} \mathrm{~kg} \\
& m_{s 2}=8,78 \cdot 10^{-3} \mathrm{~kg} ; r_{2}=0,01 \mathrm{~m}
\end{aligned}
$$

Figure 2 shows the graphs of the moment of inertia of a cylindrical body $\left(I_{b}\right)$ against the square of the distances between the point of suspension and the center of the body $\left(Z_{b}^{2}\right)$, built according to the experimental data listed in Tables 1a through 1c (lines with data points); they are numbered as 1, 3 and 5. For comparison, the solid lines 2, 4 and 6, built from the theoretical formula, are also shown in Figure 2. 
CBU I NTERNATIONAL CONFERENCE ON I NNOVATION, TECHNOLOGY TRANSFER AND EDUCATION

Figure 2: Graphs of $I_{b}$ against $Z_{b}{ }^{2}$, constructed from experimental data and theoretical calculations

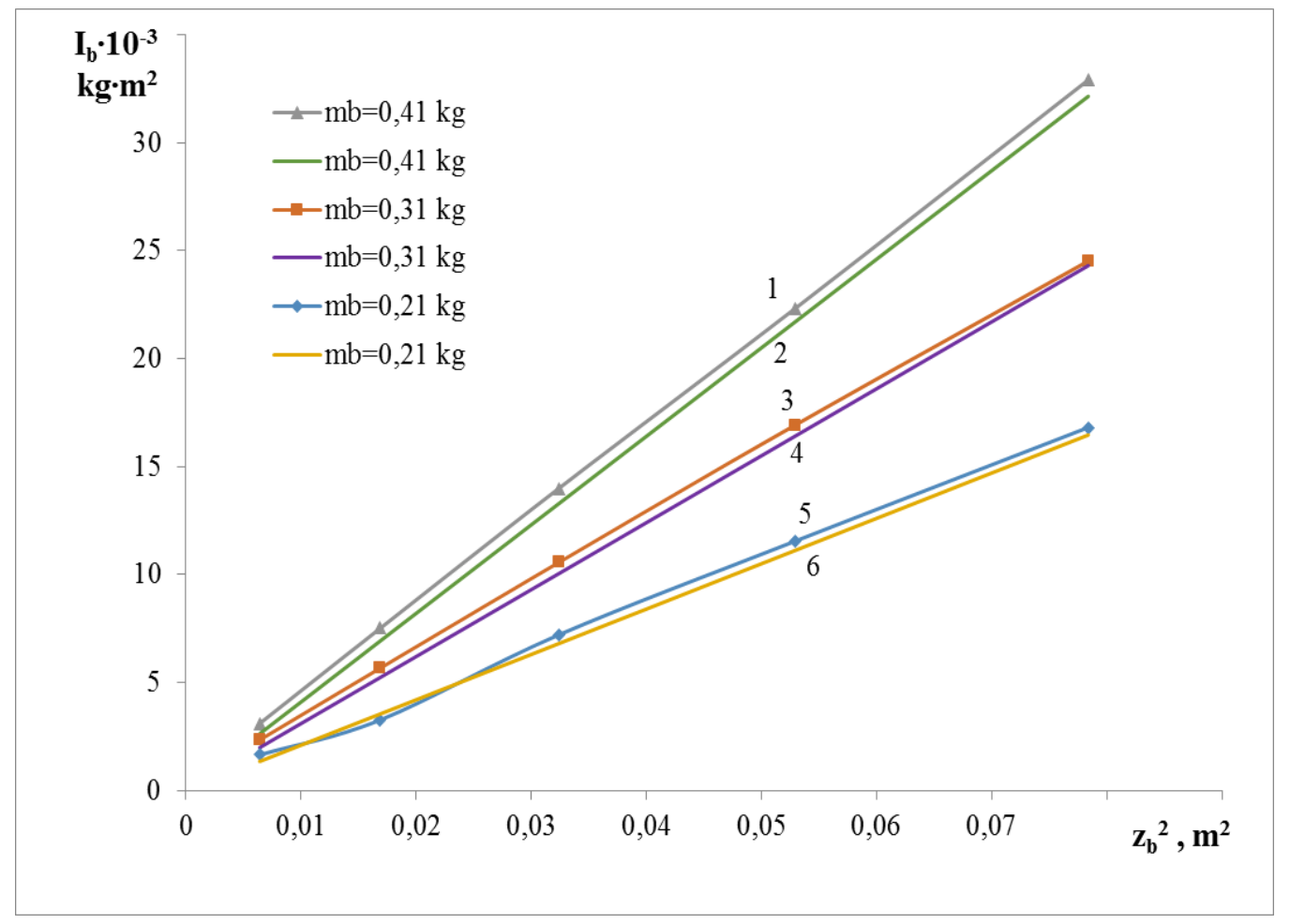

Source: Author

Table 2 shows the results of processing by the least squares method.

Figure 3 shows the graphs of the moment of inertia of a cylindrical body $\left(I_{b}\right)$ against the square of the distances between the point of suspension and the center of the body $\left(Z_{b}{ }^{2}\right)$, built according to processed experimental data (lines 1, 3 and 5) and by theoretical formula (lines 4, 5 and 6).

Table 2: The results of processing by the least squares method

\begin{tabular}{|l|l|l|l|l|}
\hline$m_{b}, \mathrm{~kg}$ & $a_{0} \cdot 10^{-3} \mathrm{~kg} \cdot \mathrm{m}^{2}$ & $a_{2}, \mathrm{~kg}$ & $\sigma_{a_{0}} \cdot 10^{-3}, \mathrm{~kg} \cdot \mathrm{m}^{2}$ & $\sigma_{a_{2}}, \mathrm{~kg}$ \\
\hline 0.21 & 0.07262 & 0.21453 & 0.10597 & 0.00411 \\
\hline 0.31 & 0.46978 & 0.30829 & 0.04590 & 0.00178 \\
\hline 0.41 & 0.51513 & 0.41307 & 0.02496 & 0.00097 \\
\hline
\end{tabular}

Source: Author 
Figure 3: Graphs of $I_{b}$ against $Z_{b}^{2}$, constructed from processed and theoretical calculations

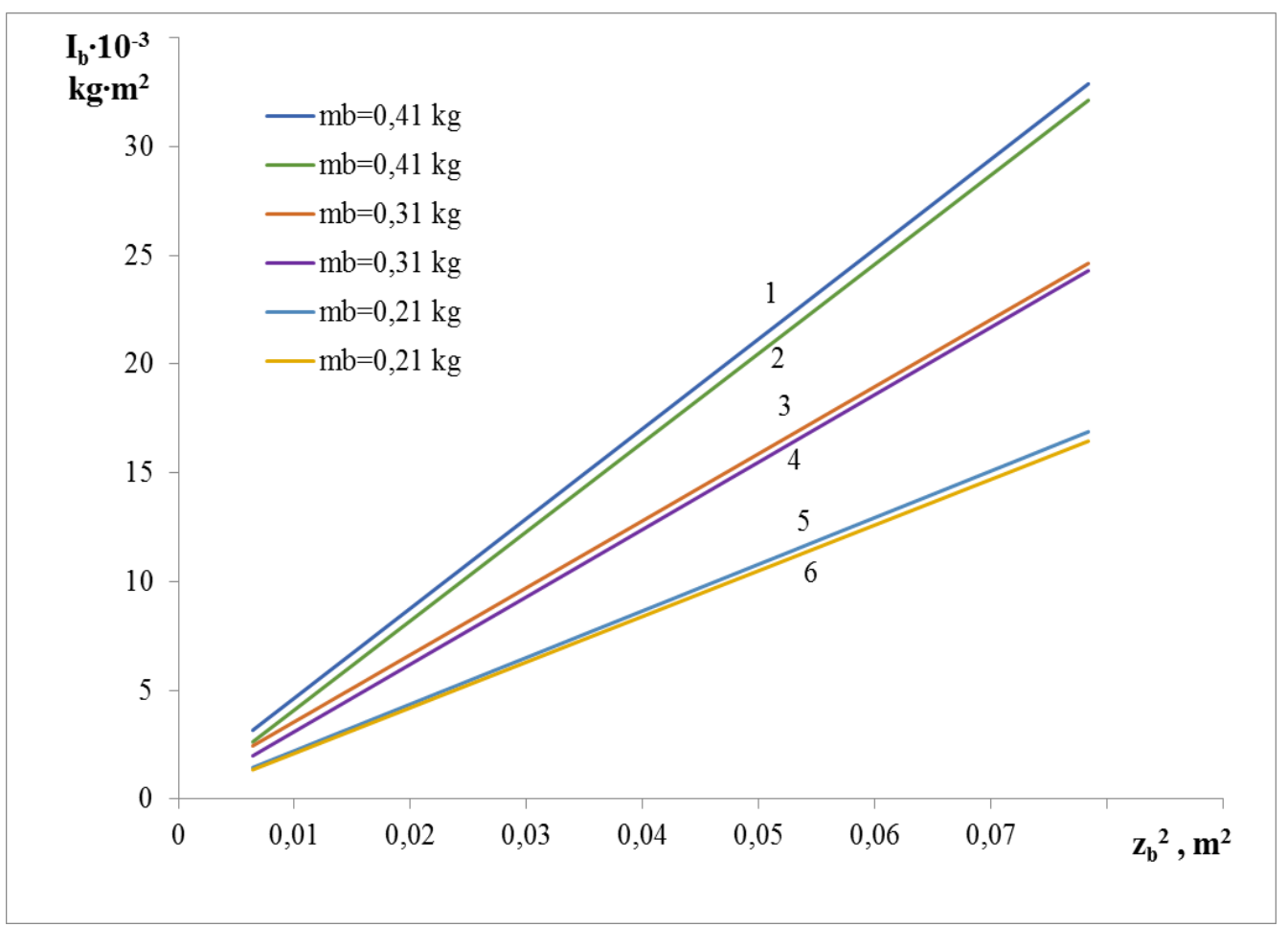

Source: Author

We can see the proximity of experimental curves to the theoretical that allows us to draw conclusions that the method of experimental verification of Steiner's Theorem is one of the most effective and easiest ways to verify the mentioned theorem. Calculation and presentation of its results can be automated, using a dialog box in visual programming system Delphi 7 (Arkhangel'skiy, 2004).

\section{Conclusion}

The article presents the experimental device, adapted for an experimental verification of Steiner's Theorem in educational laboratory settings. The technique of laboratory work on a very simple physical pendulum is developed. To experimentally determine the moment of inertia of an object under investigation (a cylindrical body), property of additivity of a physical quantity was used. Processing of results was performed with approximation of functions by the least squares method. Comparison of the experimental results with theoretical calculations shows their close proximity. Experimental work can be easily implemented with other objects with regular and irregular shapes. This allows us to recommend the experimental device and this methodology for laboratory work using physical practicum in universities as an effective and easy way to verify Steiner's Theorem. Laboratory work can be expanded with the study of damped oscillation and the definition of its characteristics: the period of oscillation, the logarithmic decrement, damping coefficient, relaxation time, the number of oscillations committed during the relaxation time, quality factor and the internal friction of vibrating system.

\section{Acknowledgement}

We express our deepest and most sincere gratitude to the Engineer, E. G. Sperchenok, in preparing the physical apparatus for carrying out the experimental work. 


\section{References}

Yevgrafova, N. N., \& Kagan, V. L. (1970). Rukovodstvo $k$ laboratornym rabotam po fizike, uchebnoye posobiye dlya radiotekhnicheskikh i elektropriborostroitel'nykh spetsial'nostey vuzov [Manual to laboratory works in physics, textbook for radio and electrical construction specialties of high schools]. Moscow, Russia: Higher school.

Korzun, I. N. (1991). Laboratornyye raboty po mekhanike i molekulyarnoy fizike [Laboratory work on mechanics and molecular physics]. Almaty, Kazakhstan: Kazakh University.

Baypakbayev, T. S., Karsybayev, M. SH., \& Salamatina A. M. (2007). Mekhanika postupatel'nogo i vrashchatel'nogo dvizheniya, metodicheskiye ukazaniya $k$ vypolneniyu laboratornykh rabot dlya studentov vsekh form obucheniya vsekh spetsial'nostey [Mechanics of translational and rotational motion, methodical instructions to laboratory works for students of all forms of education and for all specialties]. Almaty, Kazakhstan: AIPET

Akimov, A. I., Baranov, A. N., \& Saletskiy, A. M. (2000). Fizicheskiy mayatnik: Puti povysheniya tochnosti izmereniya [Physical pendulum: Ways of Increasing the Accuracy Measurements of g]. Physics in Higher Education, 6(2), 52-61.

Baypakbayev, T. S., Zavadskaya, L. V., Tonkonogaya, L. A., \& Semeneniya, V. A. (2008). Fizika: kolebaniya, metodicheskiye ukazaniya $k$ vypolneniyu laboratornykh rabot dlya studentov vsekh form obucheniya vsekh spetsial'nostey [Physics: oscillations, methodical instructions to laboratory works for students of all forms of education and for all specialties]. Almaty, Kazakhstan: AIPET.

Astapov, Ye. N., Botneva, Z. N., Kochkin, YU. P., Lednov, A.YU., Lisovskaya, M. A., Mashkin, A. G., Mel'tser-Shafran, L.V., Raskuzhina, I. V., Savinova, N. A., \& Savchenko, YU. I. (2011). Mekhanika: laboratornyy praktikum dlya studentov vsekh spetsial'nostey [Mechanics: laboratory practicum for students of all disciplines]. Magnitogorsk, Russia: MSTU.

Kachevskiy, A. N. (1998). Laboratornaya rabota: Izucheniye zatukhayushchikh krutil'nykh kolebaniy, uprugikh i neuprugikh svoystv materiala [Laboratory Project Studying of Damped Torsion Vibrations, Elasticity and Inelasticity Material Property]. Physics in Higher Education, 6(1), 105-112.

Maysova, N. N. (1970). Praktikum po kursu obshchey fiziki [Practicum on General Physics]. Moscow, Russia: Higher school.

Gladun, A. D., Alexandrov, D. A., Igoshin, F. F., Korotkov, P. F., Koryavov, V. P., Ovchinnikov, A. P., Samarskiy, YU. A., Tevryukov, A. A., \& Freynberg, G. N. (2004). Laboratornyy praktikum po obshchey fizike: Mekhanika (Tom 1) [Laboratory practicum on general physics: Mechanics (Volume 1)]. Moscow, Russia: Moscow Institute of Physics and Technology.

Vasil'yev, Ye. I., Saletskiy, A. M., \& Slepkov, A. I. (1998). Izucheniye inertsionnykh kharakteristik tverdogo tela v praktikume po obshchey fizike [Study of the Inertial Characteristics of a Rigid Body in a General Physics Laboratory]. Physics in Higher Education, 4(1), 105-112.

Koryavov, V. P. (2003). Mayatnik dlya issledovaniya nelineynykh kolebaniy [Pendulum for Study of Nonlinear Oscillations]. Physics in Higher Education, 9(4), 62-68.

Savel'yev, I. V. (2012). Kurs obshchey fiziki: Mekhanika, Molekulyarnaya fizika (Tom 1) [Course of General Physics: Mechanics, Molecular Physics (Volume 1)]. Moscow, Russia: KNORUS.

Khaykin, S. E. (2008). Fizicheskiye osnovy mekhaniki [Physical Foundation of Mechanics]. Saint-Petersburg, Moscow, Krasnodar, Russia: Printing House Doe.

Trofimova, G. I. (2008). Kurs fiziki: uchebnoye posobiye dlya vuzov [Course of Physics: Textbook for High Schools]. Moscow, Russia: Printing House Academy.

D'yakonov, V. P. (1987). Spravochnik po algoritmam i programmam na yazyke beysik dlya personal'nykh EVM [Handbook on Algorithms and Programs in BASIC Language for Personal Computers]. Moscow, Russia: Printing House Science.

Arkhangel'skiy, A. YA. (2004). Delphi 7: Spravochnoye posobiye [Delphi 7: Reference Manual]. Moscow, Russia: PC BeanPress. 